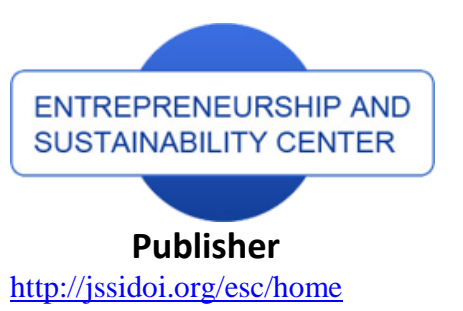

http://ssidoi.org/esc/home

\section{enterprise europe network} Business Support on Your Doorstep

\title{
START-UPS IN THE FIELD OF SOCIAL AND ECONOMIC DEVELOPMENT OF THE REGION: A COGNITIVE MODEL
}

\author{
Ludmila Orlova $^{1}$, Galina Gagarinskaya ${ }^{2}$, Yuliya Gorbunova ${ }^{3}$, Olga Kalmykova ${ }^{4}$ \\ Samara State Technical University, bld. № 244 Molodogvardeyskaya St., Samara, 443100, Russian Federation \\ E-mail: ${ }^{1}$ orlova.ludmilaviktorovna@bk.ru
}

Received 14 February 2018; accepted 25 May 2018; published 30 June 2018

\begin{abstract}
The article considers the factors influencing regional development on the part of start-ups, shows a cognitive model of such impact, and gives an analysis of scenario modeling in the Samara Region. The research results are aimed at creating favorable conditions for ensuring the progressive development of a single region and the entire Russian economy. To implement the goal, studies were carried out in the form of an expert survey aimed at assessing the impact of start-ups on regional development. The study included methods of systemic analysis, economic statistics, methods of sociological expert survey, a method of statistical data analysis, a method of qualitative peer review, and a method of cognitive modeling. The article presents the results of scientific research aimed at identifying the mutual influence of the basic factors of regional development and start-ups as an important element of the socioeconomic system. The works of many scholars are devoted to the analysis and research of the problem of innovative entrepreneurship. They reveal the aspects of studying innovative entrepreneurship in the context of improving the effectiveness of innovative activity and motivating entrepreneurship. This study highlights the importance of start-ups for the formation and development of effective regional innovation systems and actualizes investigations related to identifying the main directions in the activities of the region's start-ups. A comparative analysis of the scenarios was carried out and the most effective of them were determined for the Samara Region. The presented research results can be transferred and reproduced in any constituent entity of the Russian Federation. The obtained cognitive models can be used as basic models to back up large administrative decision-making in the field of managing the regional infrastructure for supporting small and medium-sized businesses to improve its adaptability to changes in external and internal factors and to determine the trajectories of sustainable development. In addition, the obtained models can be applied in the field of fundamental research on the functioning and development of regional socio-economic systems, as well as in applied research in modeling options for sustainable development of regional socio-economic systems.
\end{abstract}

Keywords: start-ups; business; innovative entrepreneurship; social and economic development; factors; cognitive model

Reference to this paper should be made as follows: Orlova, L.; Gagarinskaya, G.; Gorbunova, Y.; Kalmykova, O. 2018. Start-ups in the field of social and economic development of the region: a cognitive model, Entrepreneurship and Sustainability Issues 5(4): 795811. http://doi.org/10.9770/jesi.2018.5.4(7)

JEL Classifications: A14, M21, R11

\section{Introduction}

As shown by the domestic practice and international experience, the greatest effect in the implementation of priority areas of economic and social development can be achieved only if the reforms carried out are innovative. In turn, the scale and pace of innovative transformations directly depend on the degree of 
The International Journal

ENTREPRENEURSHIP AND SUSTAINABILITY ISSUES

ISSN 2345-0282 (online) http://jssidoi.org/jesi/

2018 Volume 5 Number 4 (June)

http://doi.org/10.9770/jesi.2018.5.4(7)

involvement and actual participation of both the state and private business in the innovations. Today, the innovation process is the determining factor in the effective development of production. A special place in the structure of modern small and medium-sized business is occupied by innovative entrepreneurship (Vojtovic, 2016; Wroblowska, 2016; Kozubikova et al., 2017; Tvaronavičienė, 2017; Razminienè, Tvaronavičienè, 2017), which is a source of generating innovative ideas and developments, socio-economic development of the regions of the Russian Federation (Rakhimova, 2014; Vinogradova, 2015; Tatarkin, 2013; Akhmetshin, 2017; Akhmetshin et al., 2017; Rakhimova, 2014; Vinogradova, 2015; Tatarkin, 2013; Afonin \& Orlova, 2017). A constant assessment of the mutual influence of regional development factors and start-ups is an integral part of the entrepreneurship support system. The formalization of such an assessment based on the method of cognitive modeling has become the goal of this scientific research.

The purpose of the study was to identify the mutual influence of the basic factors of regional development and start-ups on the basis of the cognitive modeling method.

The tasks of this research were to determine the factors affecting the regional development on the part of startups; show scenario modeling of the impact of start-ups on regional development; make a comparative analysis of scenarios and determine the most effective of them for the Samara Region.

The scientific novelty lies in revealing specific features of the influence of start-ups in the field of social and economic development of the region and presenting the most effective scenario of social and economic development of the Samara Region through the development of business start-ups based on the method of cognitive modeling.

The research hypothesis: the regional management of socio-economic development processes is influenced by the administrative regulating measures that dominate the mechanisms of competitive, market-based selfregulation. Partnership relations between the regional authorities and small innovative business provide a sustainable socio-economic development of both the business itself and the region as a whole.

\section{Literature review}

In the world practice, the innovative entrepreneurship management mechanisms were studied by Drucker (2007), Hayek (2005), Schumpeter (2007), Say (2001) and others. The problems of innovative entrepreneurship were considered by such Russian scholars and experts as Kosharnaya (2016), Maslennikova (2001), Medynsky and Skamay (2005), Obraztsova and Chepurenko (2008) etc.

The works of Vasiliev (2000), Gokhberg (2003), Glazyev (1993), Dagaev (2000), Zavlin et al. (2004), Kazantsev et al. (2003), Kovalev (2000), Livshits and Livshits (2000), Lvov (2003), Fatkhutdinov (2004) and other scholars are devoted to the problems of increasing the effectiveness of innovative activities.

Theoretical and practical issues and peculiarities of the formation and development of regional innovative systems, the evolution of functions of the state and the business sector in the innovation process are disclosed in the numerous works of scientists, e.g. Archibugi, Howells and Michie (1999), Autio (1998), Dosi et al. (1988), Lundvall (1992), Nelson (1993), Todtling and Kaufmann (1999), Howells (2004) and others.

At the present stage innovative activities become one of the most important systemic factors of economic growth, increasing the competitiveness of domestic products, ensuring the economic security of the country. A special role is assigned to the social and economic development of the regions through the development of business start-ups. 
The International Journal

ENTREPRENEURSHIP AND SUSTAINABILITY ISSUES

ISSN 2345-0282 (online) http://jssidoi.org/jesi/

2018 Volume 5 Number 4 (June)

http://doi.org/10.9770/jesi.2018.5.4(7)

\section{Methodology}

The study, in the form of an expert survey, focused on assessing the factors affecting the regional development on the part of start-ups, was conducted:

- on the basis of the analysis of various aspects of socio-economic activities of the regions (the legislative framework for the development of business, the grounds and practice of increasing the transparency of power in modern Russia, the analysis of problem situations in the relationship of civil society with local governments, especially the financing of innovative projects in the regions);

- on the basis of an expert survey conducted in April (stage 1), in May (stage 2) in 2017 (13 experts from the Samara Region). The survey data was processed using the SPSS program.

Technical support of the conducted research was carried out with the help of the "Analyst" program. The program is designed for cognitive modeling of weakly-structured processes, studying their dynamics, constructing predictive scenarios for the development of the situation, analyzing and predicting the consequences of managerial decisions (Dakhin et al., 2011).

The cognitive approach is widely used in the study of socio-economic and political processes. Its main advantage is the ability to conduct the qualitative simulation of the situation development, for example, from negative initial states to positive ones, as well as in the possibility of studying the behavior of the system for stability (predictability).

\section{Results}

According to the results of the expert survey, seven respondents refer themselves to the economic sphere, two respondents characterize themselves in the context of belonging to the sphere of jurisprudence, and four persons are specialists in the field of sociology.

Let us consider the problem situations of the socio-economic process through the implementation of the sequence of the following steps:

- identifying a set of the most significant factors describing the problem situation, the process, the system (Table 1);

- singling out target and managed factors;

- establishing the cause-effect relationships between the factors.

Table 1. Correspondence between the analytical, statistical data and the factors of the cognitive modeling system

\begin{tabular}{|l|l|l|}
\hline & \multicolumn{1}{|c|}{ Statistical, expert data } & Factors of the cognitive modeling system \\
\hline 1. & $\begin{array}{l}\text { The number of start-up projects with an evolutionary development path, the } \\
\text { annual turnover of such projects }\end{array}$ & F1, Sustainable start-up \\
\hline 2. & $\begin{array}{l}\text { Number of business incubators, resource centers for non-profit organizations, } \\
\text { social entrepreneurship, similar institutions for the generation of business } \\
\text { culture }\end{array}$ & F2, Business culture incubators \\
\hline 3. & Amount of private investment & F4, Private investment \\
\hline 4. & Amount of public investment & $\begin{array}{l}\text { F5, Quality of the regulatory and legal } \\
\text { framework }\end{array}$ \\
\hline 5. & Number of PPPs, IPPs, expert assessments & F6, Team professionalism \\
\hline 6. & Correspondence of the competences of the start-up technology team members \\
\hline 7. & $\begin{array}{l}\text { Employment in the small and medium-sized business sector, incl. IE; wages } \\
\text { in SMEs, the average volume of annual turnover in rubles. }\end{array}$ & F7, Entrepreneurship development \\
\hline 8. & $\begin{array}{l}\text { Number of PPPs, IPPs, enterprises, projects and structures with the } \\
\text { participation of universities, on the basis of universities or research institutes; }\end{array}$ & F8, Interaction of science, business and power \\
\hline 9. & Number of legislative initiatives of citizens, NPOs, incl. in the sphere of & F9, Innovative activity of the population \\
\hline
\end{tabular}


The International Journal

ENTREPRENEURSHIP AND SUSTAINABILITY ISSUES

ISSN 2345-0282 (online) http://jssidoi.org/jesi/

2018 Volume 5 Number 4 (June)

http://doi.org/10.9770/jesi.2018.5.4(7)

\begin{tabular}{|c|c|c|}
\hline & $\begin{array}{l}\text { business; number of referendums initiated by citizens; number of participants } \\
\text { in grant competitions }\end{array}$ & \\
\hline 10. & $\begin{array}{l}\text { \% of innovative products in the region, the number of enterprises that produce } \\
\text { innovative products, the volume of manufactured innovative products in the } \\
\text { region (UM/RUB); The volume of innovative goods and services provided by } \\
\text { SMEs }\end{array}$ & F10, Innovative entrepreneurship development \\
\hline 11. & $\begin{array}{l}\text { The level of income of the population, the level of labor productivity, } \\
\text { revenues of the region }\end{array}$ & F11, Socio-economic state of the region \\
\hline 12. & $\begin{array}{l}\text { Human development index (HDI), GRP per capita, average life expectancy of } \\
\text { the population in the region, birth rate, degree of satisfaction of housing } \\
\text { demand, quality/convenience of medical services, quality/convenience of } \\
\text { educational services, quality/convenience of roads, quality/convenience of the } \\
\text { environment for the disabled, quality/convenience of public and municipal } \\
\text { services }\end{array}$ & F12. Quality of life of the region's population \\
\hline 13. & The volume of actual demand for innovation in the region & F13. Demand for innovation \\
\hline 14. & $\begin{array}{l}\text { Number and effectiveness of government programs to support innovation } \\
\text { activities in the region. Number of patents in the region }\end{array}$ & F14, Innovative policy of the region \\
\hline 15. & $\begin{array}{l}\% \text { of the introduction of ICT in the sphere of business, state, municipal } \\
\text { government, the percentage of computer literacy of the workable population, } \\
\text { the number of citizens receiving government services through a private office }\end{array}$ & F15, Informatization of the region \\
\hline 16. & $\begin{array}{l}\text { The number of complaints to the Ombudsman for the rights of entrepreneurs, } \\
\text { the number of collective appeals of entrepreneurs for this reason }\end{array}$ & F16, Administrative barriers \\
\hline 17. & Number of corruption cases, incl. those brought to trial & F17, Corruption \\
\hline 18. & $\begin{array}{l}\text { The inappropriate use of investments in start-up projects, violation of } \\
\text { legislation, the number of administrative, criminal fraud charges in the } \\
\text { business incubator sphere, the prevalence of the 'carousel' of business teams } \\
\text { on the basis of business incubators }\end{array}$ & F18, Fraudulent activities \\
\hline 19. & $\begin{array}{l}\text { Non-viable start-ups, existing only with the availability of benefits, } \\
\text { government support, lobbying. Number of non-viable projects that have } \\
\text { passed through the support system }\end{array}$ & F19, Rogue start-ups \\
\hline 20. & $\%$ of quality work with start-up projects & F20, Dysfunctions \\
\hline 21. & $\begin{array}{l}\text { The proportion of the retirement age population, the proportion of youth, the } \\
\text { number, the proportion of unemployed in the region }\end{array}$ & F21, Demographic profile \\
\hline 22. & Technological profile of the region (dominant technological setups) & F22. Technological setup \\
\hline 23. & $\begin{array}{l}\text { The volume of financing the economy from the federal budget on the basis of } \\
\text { state order. Volumes of state procurement in the region }\end{array}$ & F23, State order \\
\hline
\end{tabular}

In this case, in the opinion of the experts, the social and economic development of the region is under a weak influence of the judicial power and the depressed community (assessed as 0.1-0.3) and under a moderate influence of shadow finance, criminality, rogue start-ups (assessed as 0.3-0.5). The other factors have a strong influence (assessed as 0.5-1). In addition, the experts named the focus of start-up on the international markets, a favorable urban environment, a comfortable social living environment, an innovative activity of the population and some others among the additional factors of influence.

Let us consider the qualitative-quantitative analysis of the factors of innovative development of the Samara Region to determine the list of statistically determined and expertly defined values of the indicators. Statistically determined indicators are reduced and compared with the cognitive modeling factors according to the "1 factor -1 statistical indicator" principle. Expertly determined indicators are identified in the course of an expert survey.

To construct a cognitive model of mutual influence of the start-up factor and the main factors of socioeconomic development of the region, an expert comparison of factors (indicators) of the experimental cognitive model and statistical indicators characterizing social and economic development was carried out.

Table 2 provides a list of factors of the cognitive model and the corresponding statistical indicators with the dynamics for the period of 2011-2015. The table is accompanied by the results (Table 2a) of the correlation 
The International Journal

ENTREPRENEURSHIP AND SUSTAINABILITY ISSUES

ISSN 2345-0282 (online) http://jssidoi.org/jesi/

2018 Volume 5 Number 4 (June)

http://doi.org/10.9770/jesi.2018.5.4(7)

analysis for quantitatively measurable factors of the cognitive model, for which cause-effect relationships are indicated.

Table 2. Factors and indicator of the Samara Region

\begin{tabular}{|c|c|c|c|c|c|c|c|}
\hline & The model factors & Statistical indicators & 2011 & 2012 & 2013 & 2014 & 2015 \\
\hline $\mathrm{F} 2$ & $\begin{array}{l}\text { Business culture } \\
\text { incubators }\end{array}$ & $\begin{array}{l}\text { The number of organizations } \\
\text { engaged in research and } \\
\text { development (units) }\end{array}$ & 62 & 61 & 62 & 62 & 76 \\
\hline F3 & Private investment & $\begin{array}{l}\text { Private investment (RUB } \\
\text { mln.) }\end{array}$ & & 191186.5 & 239143.1 & 296197.1 & 279102.3 \\
\hline $\mathrm{F} 4$ & Public investment & Public investment (RUB mln.) & 182575.3 & 213021.8 & 269736.5 & 321759.5 & 298746.4 \\
\hline F7 & $\begin{array}{c}\text { Entrepreneurship } \\
\text { development }\end{array}$ & $\begin{array}{c}\text { Average number of the SME } \\
\text { employees (persons) }\end{array}$ & 359.3 & 369.3 & 354.8 & 357.2 & 375.9 \\
\hline F9 & $\begin{array}{l}\text { Innovative activity of } \\
\text { the population }\end{array}$ & $\begin{array}{l}\text { Patent applications filed } \\
\text { (units) }\end{array}$ & 1049 & 1106 & 987 & 883 & 932 \\
\hline F10 & $\begin{array}{c}\text { Innovative } \\
\text { entrepreneurship } \\
\text { development }\end{array}$ & $\begin{array}{c}\text { The share of organizations } \\
\text { that implement technological } \\
\text { innovation }\end{array}$ & 8.5 & 5.7 & 5.0 & 5.3 & 4.7 \\
\hline F12 & $\begin{array}{l}\text { Quality of life of the } \\
\text { population }\end{array}$ & $\begin{array}{l}\text { Expectancy of life of the } \\
\text { population (years) }\end{array}$ & 69.0 & 69.7 & 69.4 & 69.6 & 70.4 \\
\hline F14 & Innovative policy & Patents issued (units) & 720 & 843 & 921 & 840 & 779 \\
\hline F15 & $\begin{array}{l}\text { Informatization of the } \\
\text { region }\end{array}$ & $\begin{array}{c}\text { Organizations that had a } \\
\text { website on the Internet (in \% } \\
\text { of the total number of } \\
\text { organizations surveyed) }\end{array}$ & 33.7 & 33.5 & 31.9 & 31.6 & 31.0 \\
\hline F17 & Corruption & $\begin{array}{c}\begin{array}{c}\text { The number of registered } \\
\text { crimes qualified as "Bribery" } \\
\text { (units) }\end{array} \\
\end{array}$ & 279 & 172 & 204 & 230 & 164 \\
\hline $\mathrm{F} 21$ & Demographic profile & $\begin{array}{c}\text { Number of the retirement age } \\
\text { population at the age of 55-59 } \\
\text { (as of January 1, persons) }\end{array}$ & 931.6 & 943.3 & 952.9 & 962.8 & 970.5 \\
\hline $\mathrm{F} 22$ & Technological setup & $\begin{array}{c}\text { Share of high-tech and } \\
\text { knowledge-intensive products } \\
\text { in the GRP }(\%)\end{array}$ & 27.1 & 27.4 & 26.0 & 26.4 & 25.9 \\
\hline F23 & State order & $\begin{array}{l}\text { Investments in R\&D (RUB } \\
\text { thous.) }\end{array}$ & 408.4 & 101.0 & 336.6 & 2090.0 & 672.9 \\
\hline
\end{tabular}

Table 2a. Results of the correlation analysis for the Samara Region

\begin{tabular}{|c|r|}
\hline $\mathrm{F} 2 * \mathrm{~F} 14$ & -0.3134705 \\
\hline $\mathrm{F} 3 * \mathrm{~F} 7$ & -0.12931591 \\
\hline $\mathrm{F} 4 * \mathrm{~F} 23$ & 0.717239799 \\
\hline $\mathrm{F} 7 * \mathrm{~F} 9$ & 0.127770444 \\
\hline $\mathrm{F} 9 * \mathrm{~F} 7$ & 0.127770444 \\
\hline $\mathrm{F} 9 * \mathrm{~F} 21$ & -0.80892326 \\
\hline $\mathrm{F} 10 * \mathrm{~F} 9$ & 0.489171302 \\
\hline $\mathrm{F} 12 * \mathrm{~F} 10$ & -0.75032044 \\
\hline $\mathrm{f} 12 * \mathrm{f} 14$ & 0.059763538 \\
\hline $\mathrm{f} 14 * \mathrm{~F} 10$ & -0.68731671 \\
\hline
\end{tabular}


The International Journal

ENTREPRENEURSHIP AND SUSTAINABILITY ISSUES

ISSN 2345-0282 (online) http://jssidoi.org/jesi/

2018 Volume 5 Number 4 (June)

http://doi.org/10.9770/jesi.2018.5.4(7)

\begin{tabular}{|l|r|}
\hline F15*F14 & -0.31422929 \\
\hline F15*F17 & 0.442956368 \\
\hline
\end{tabular}

Let us consider the most significant data of the expert survey conducted in May 2017. The survey involved 13 experts. The survey data were processed using the SPSS program.

Tables 3-6 give the data that are significant for cognitive modeling.

Table 3. Estimates of the proportion of successful, sustainable start-ups in the total mass of start-ups in the region (in $\% \%$ of the number of respondents in the region)

\begin{tabular}{|l|c|}
\hline Proportion of successful, sustainable start-ups in the total mass of start-ups & The Samara Region \\
\hline approximately up to 10\% of the sustainable start-ups & 61.5 \\
\hline approximately up to 30\% of the sustainable start-ups & 15.4 \\
\hline approximately up to 50\% of the sustainable start-ups & 7.7 \\
\hline approximately up to 70\% of the sustainable start-ups & 15.4 \\
\hline
\end{tabular}

The obtained data allow drawing a conclusion that in the Samara region the experts perceive the nuances of start-ups' states most differentially, which is associated with a wide variety of these practices and with a wider competitive field of business and expert standpoints. On the one hand, there is a greater 'diversity' of opinions, but, on the other hand, it is an indirect indicator of a more developed system of market relations, that is, the of entrepreneurship development (F7), including entrepreneurship in the market of expert appraisal: expert assessments are distributed according to four standpoints out of four. Proceeding from this, it can be ascertained that in the Samara Region the level of entrepreneurship development is slightly (weakly) exceeded.

Table 4. Opinions about the differences in the impact of various sources of investment in start-ups

\begin{tabular}{|l|c|}
\hline $\begin{array}{l}\text { Is it possible to consider that with state investments in start-ups, the number of rogue start-ups (a kind of business } \\
\text { rejects) is higher than for the same volumes of private investments, where the number of rogue start-ups is lower? }\end{array}$ & $\begin{array}{l}\text { The Samara } \\
\text { Region }\end{array}$ \\
\hline Yes & 61.5 \\
\hline No & 38.5 \\
\hline
\end{tabular}

These tables show that in the Samara region, a slightly larger number of experts believe that with public investments in start-ups, the number of rogue start-ups (a kind of business rejects) is higher than with private investments. This enables to draw a conclusion about the indirect, weak negative component in the linkage of factors (F4) Public investment $\rightarrow$ (F19) Rogue start-up.

Table 5. Estimates of the intensity of the influence exerted by negative social phenomena on the size of the share of the rogue start-ups in the region (in average points)

\begin{tabular}{|l|l|}
\hline $\begin{array}{l}\text { If you think that corruption, administrative barriers, fraudulent activities affect the share of the } \\
\text { rogue start-ups in your region, how do you assess the intensity of this influence? (from 0 to 1, where } \\
0.1 \text { is weak significance, and 1 is strong significance) }\end{array}$ & The Samara Region \\
\hline Corruption & .7154 \\
\hline Administrative barriers & .5846 \\
\hline Fraudulent activities & .5769 \\
\hline
\end{tabular}

The data show that experts recognize that corruption, administrative barriers and fraudulent activities affect the increase in the share of rogue start-ups in the region. At the same time, the intensity of such influence has weak differences for different factors. This means that it is possible to distinguish in the Samara region that the influence of the factor (F17) "Corruption" and (F18) "Fraudulent activities" on the factor (F19) "Rogue start-up" has a weak deviation towards a higher intensity (i.e., F17 and F18 affect the increase in factor F19 slightly more actively). 
The International Journal

ENTREPRENEURSHIP AND SUSTAINABILITY ISSUES

ISSN 2345-0282 (online) http://jssidoi.org/jesi/

2018 Volume 5 Number 4 (June)

http://doi.org/10.9770/jesi.2018.5.4(7)

Table 6. Estimates of the degree of influence of the start-ups' mass on the growth of innovative economy of the region (in average points)

\begin{tabular}{|l|l|}
\hline $\begin{array}{l}\text { If the influence of the mass exists, how do you assess the power of this influence? (from 0 to 1, where 0.1 is weak } \\
\text { significance, and } 1 \text { is strong significance). }\end{array}$ & $\begin{array}{l}\text { The Samara } \\
\text { Region }\end{array}$ \\
\hline Sustainable start-ups (positive influence) & .5769 \\
\hline Rogue start-ups (negative influence) & .5154
\end{tabular}

Expert estimates of the power of influence of the rogue start-ups' mass on the regional innovative development in the Samara Region are significantly high. Indirectly it means that there is a slight excess of the negative influence of the factor (F19) "Rogue start-up" on the factor (F10) "of Innovative entrepreneurship development" in the Samara Region. Accounting for this parameter in the Samara region allows considering the specifics of the region in this regard.

According to experts, the significance of the state order (financing from the state budget) for the economy and social sphere of the region was estimated as -0.7 (in average points).

Data of the experts' estimates on the significance of state orders for the economy and social sphere reflects the background level of budgetary dependence of the economy and the social sphere (Dobrenkov et al., 2017).

The experts assessed the effective activity of business incubators at the level of 0.5 (in average points). Data of the experts' estimates show that experts of the Samara Region highly appreciate the effective activity of incubators. This, firstly, confirms the specifics of the region associated with a freer economic market space. Secondly, this means that the influence of the factor (F2) "Business culture incubators" on the factor (F1) "Sustainable start-up" has a slight excess.

In general, innovative entrepreneurship is developing most successfully in the Samara Region. The region is out-grossed by the more innovatively active Russian regions, such as the Moscow Region, the Republic of Tatarstan, the Sverdlovsk Region, including by the share of organizations that implement technological innovation.

The peculiarities of the interaction of the system factors, obtained as a result of the analysis of statistical indicators and expert estimates, are loaded into the "Analytic" program to create cognitive matrices for the region for scenario cognitive modeling.

Basing on the expertise and the analytical data in the "Analytic" program, the basic cognitive model "StartUps in the Field of Social and Economic Development of the Region" is formed, not taking specific regional features into account.

Modeling is carried out for the period of the next presidential cycle of Russia 2018-2024 (6 years).

Scenarios of socio-economic development of the Samara Region through the development of business startups are presented as follows. 
The International Journal

ENTREPRENEURSHIP AND SUSTAINABILITY ISSUES

ISSN 2345-0282 (online) http://jssidoi.org/jesi/

2018 Volume 5 Number 4 (June)

http://doi.org/10.9770/jesi.2018.5.4(7)

\section{Scenario 1}
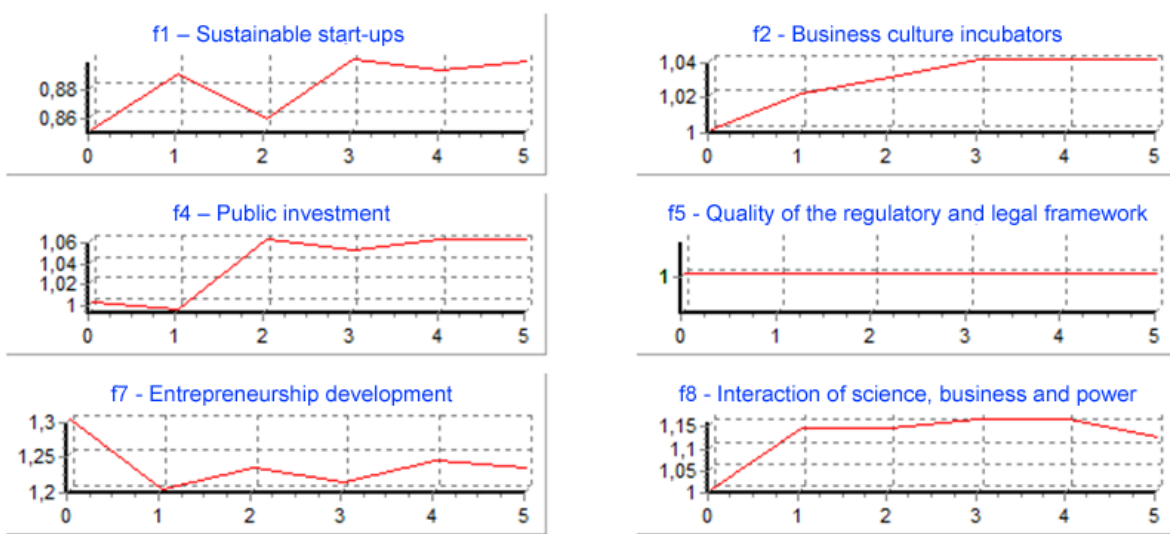

55 - Quality of the regulatory and legal framework

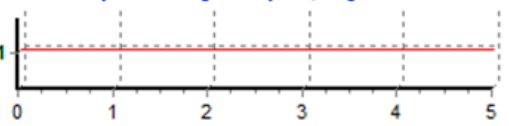

8 - Interaction of science, business and power

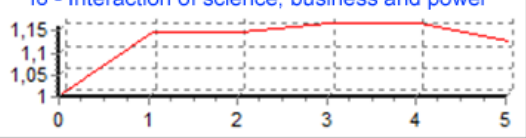

f11 - Socio-economic development of the region

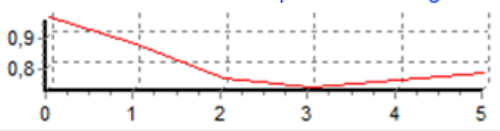

f14 - Quality of the innovative policy of the region
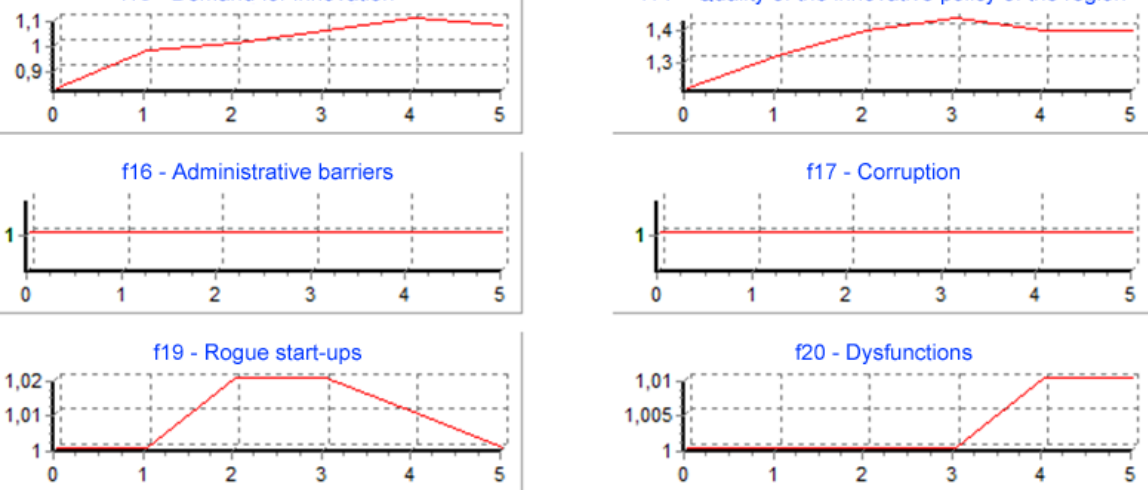

f22 - Technological setup

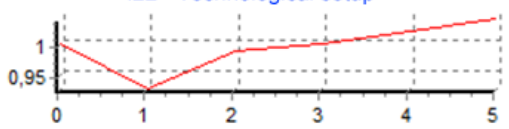

f17 - Corruption
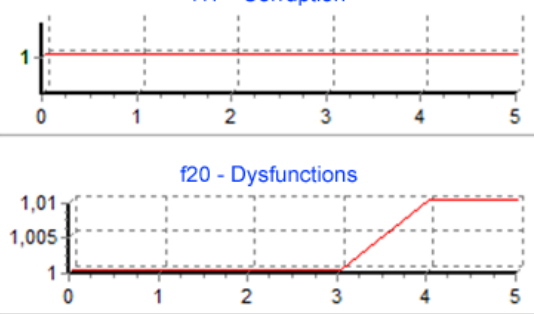

f23 - State order

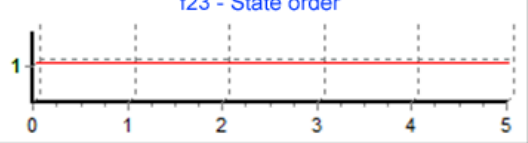

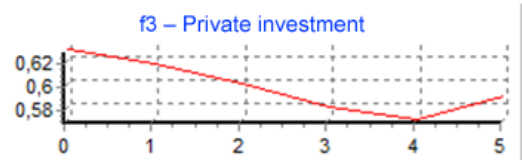

f6 - Team professionalism

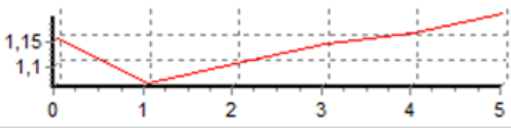

f9 - Innovative activity of the population

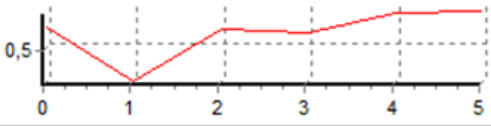

f12 - Quality of life of the region's population

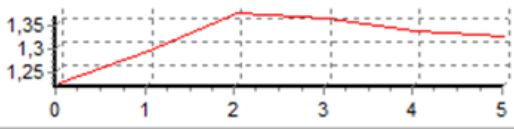

f15 Information development of the region
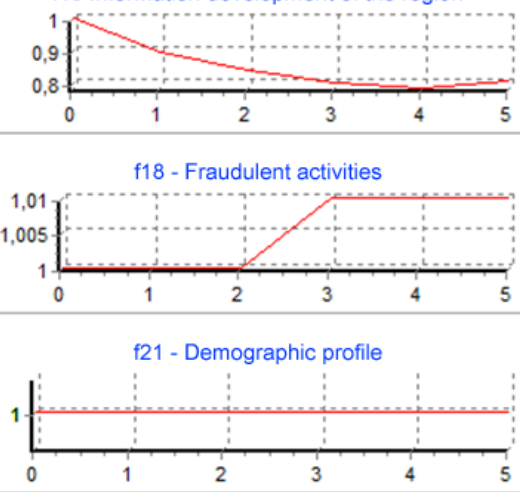

\section{Comment}

The results of the modeling show that in the perspective of six years the quantity trend of the sustainable startups is nonmonotonic: the decrease in the middle of the period by $11 \%$ is changed by a slight increase by $3 \%$ of the lower level later on. Thus, if the trend is maintained, for 100 start-ups in 2017, their number will increase to 103 units by 2026 . The number of the rogue start-ups will remain at the level of the previous four years.

There is a negative trend: a decrease in the entrepreneurship development (15\%), the innovative entrepreneurship development (17\%), innovation activity of the population (27\%), and public investment $(7 \%)$.

In this scenario, there is also a decrease in the level of socio-economic development of the region by $12 \%$, a slight increase in dysfunction and fraudulent activities. This scenario cannot be regarded as the most effective. 
The International Journal

ENTREPRENEURSHIP AND SUSTAINABILITY ISSUES

ISSN 2345-0282 (online) http://jssidoi.org/jesi/

2018 Volume 5 Number 4 (June)

http://doi.org/10.9770/jesi.2018.5.4(7)

\section{Scenario 2}
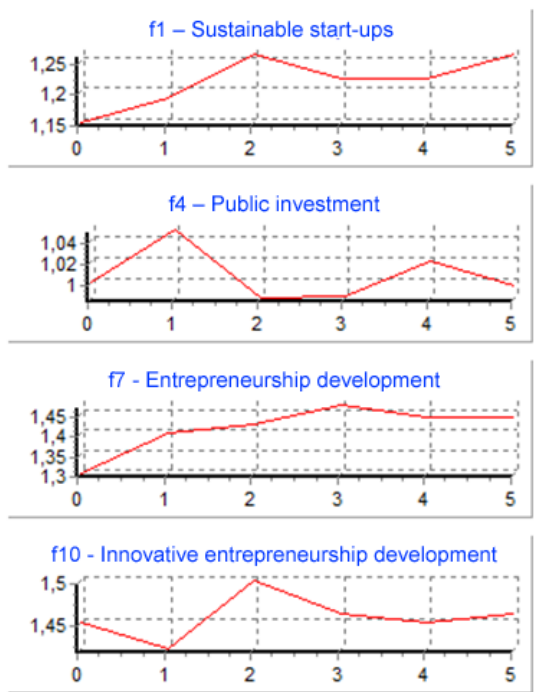

f13 - Demand for innovation

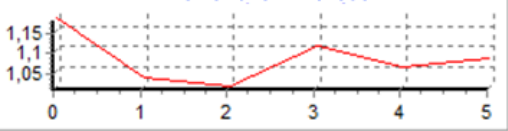

f16 - Administrative barriers
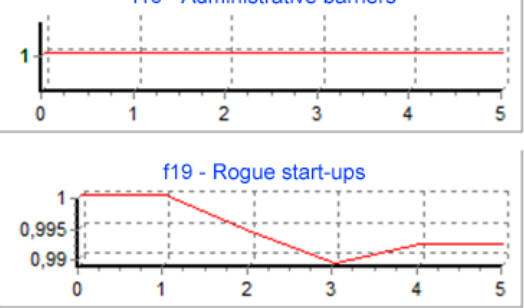

f22 - Technological setup

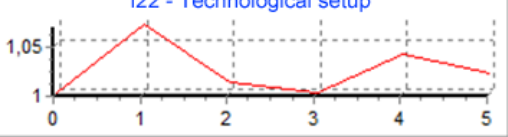

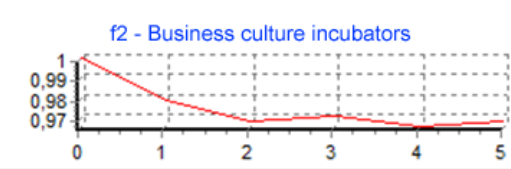

f5 - Quality of the regulatory and legal framework
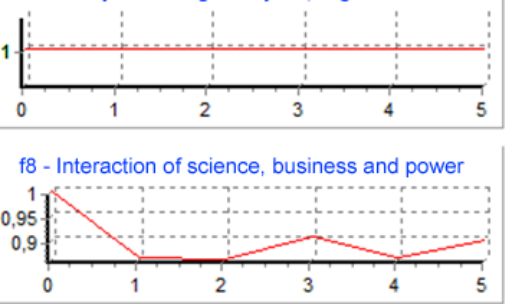

f11 - Socio-economic development of the region

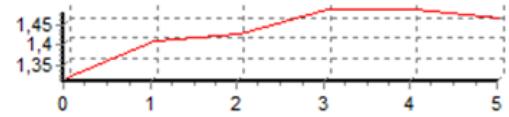

f14 - Quality of the innovative policy of the region

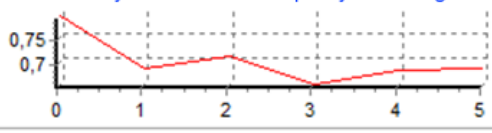

f17 - Corruption
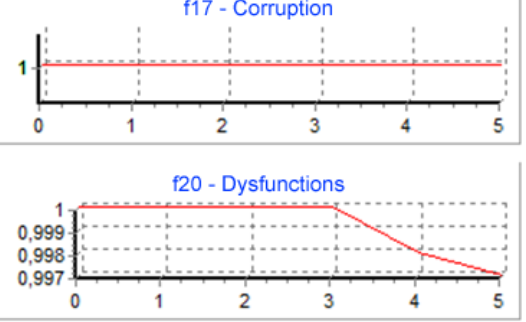

f23 - State order

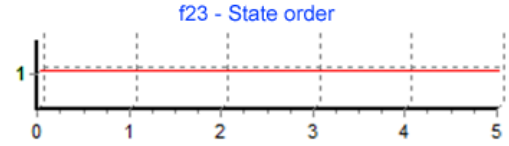

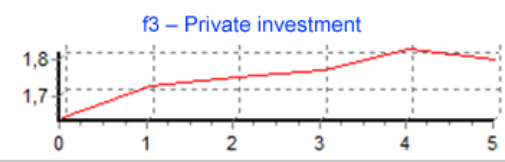

f6 - Team professionalism

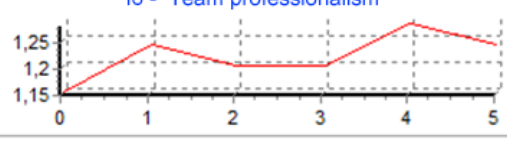

f9 - Innovative activity of the population

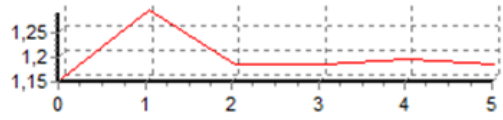

$\mathrm{f} 12$ - Quality of life of the region's population

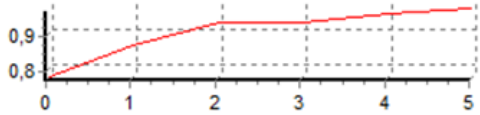

f15 Information development of the region
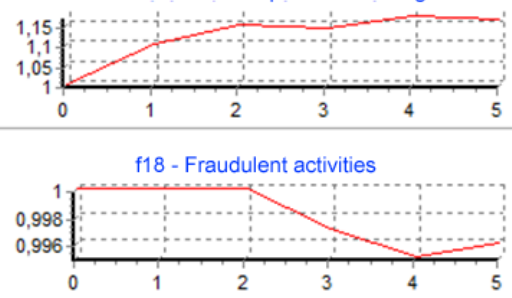

21 - Demographic profile

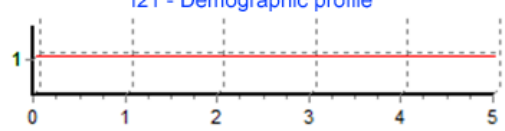

\section{Comment}

This scenario allows for conclusion that the number of the sustainable start-ups will grow by $16 \%$ in six years; however, the number of the rogue start-ups will decrease monotonically by $0.5 \%$ per year. Social and economic development will grow by $50 \%$ in six years. This scenario can be considered as acceptable, but it does not ensure a reduction in the level of corruption, administrative barriers and the growth of state orders, despite a slight decrease in fraud $(1.75 \%)$ and dysfunction $(0.4 \%)$. Therefore, it cannot be regarded as the most effective one. 
The International Journal

ENTREPRENEURSHIP AND SUSTAINABILITY ISSUES

ISSN 2345-0282 (online) http://jssidoi.org/jesi/

2018 Volume 5 Number 4 (June)

http://doi.org/10.9770/jesi.2018.5.4(7)

\section{Scenario 3}
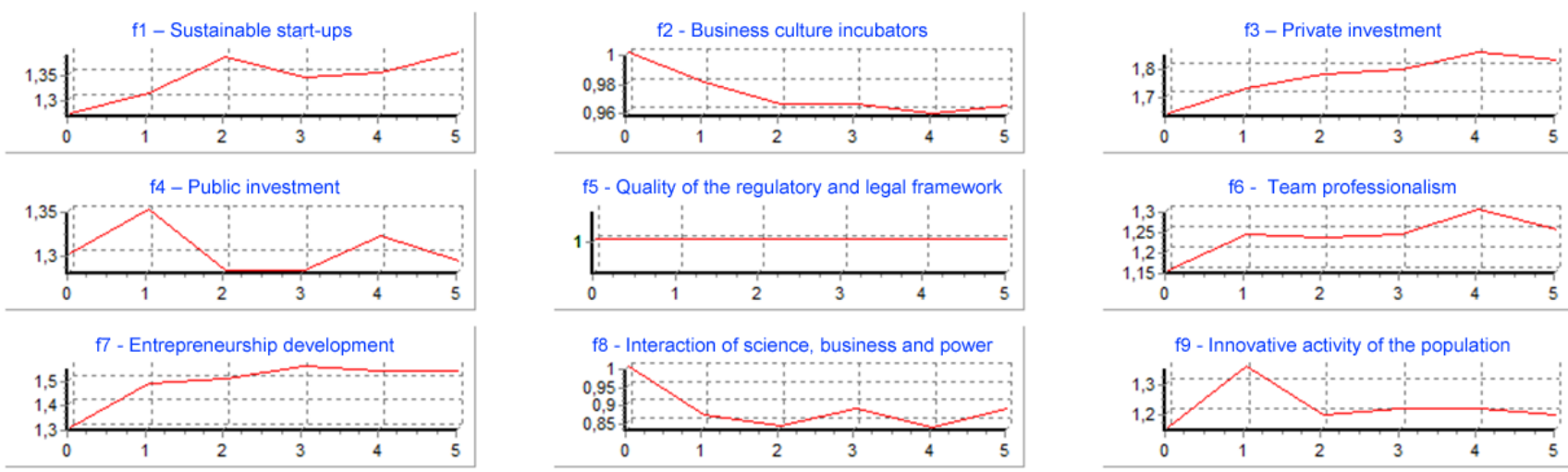

f6 - Team professionalism

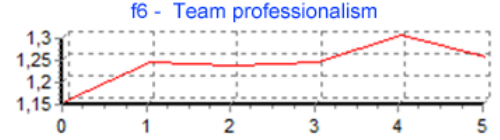

f8 - Interaction of science, business and power

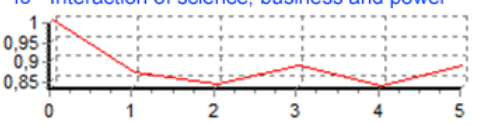

f9 - Innovative activity of the population

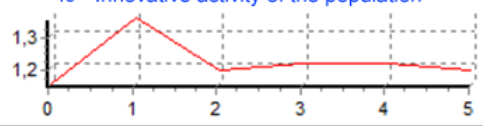

f10 - Innovative entrepreneurship development

f11 - Socio-economic development of the region

$\mathrm{f} 12$ - Quality of life of the region's population
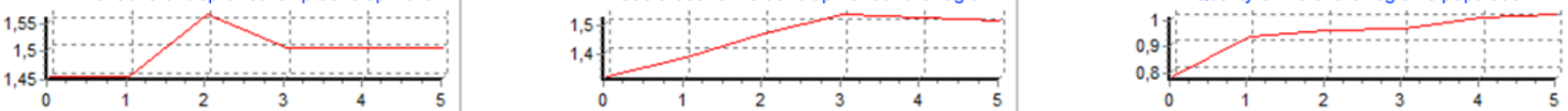

f13 - Demand for innovation

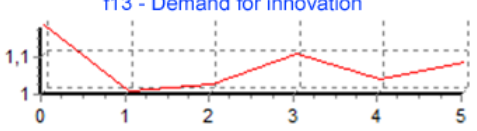

f14 - Quality of the innovative policy of the region

f15 Information development of the region
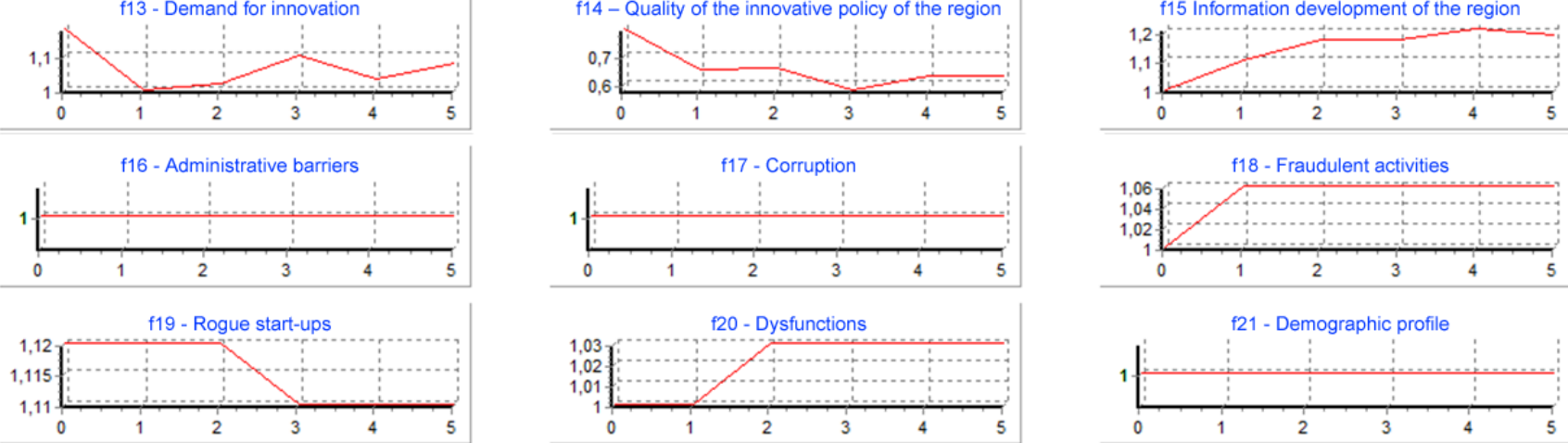

f20 - Dysfunctions

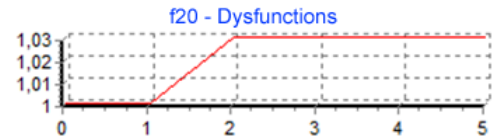

f21 - Demographic profile
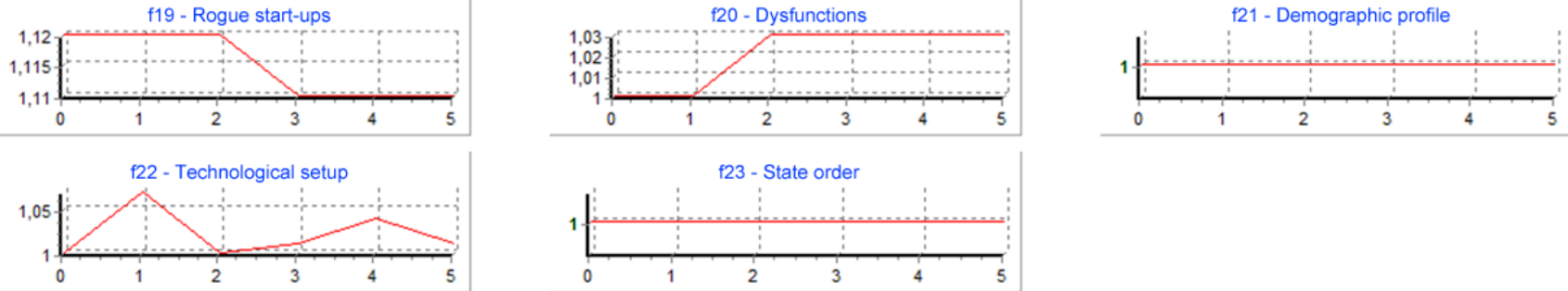

\section{Comment}

The analysis of Scenario 3 enables to state a monotonous growth of the sustainable start-ups (by $33 \%$ over the period under review), with a simultaneous decrease in the number of the rogue start-ups by $2.7 \%$ and some slowdown at the end of the period.

Other factors show a positive upward trend: entrepreneurship development (50\%) and innovative entrepreneurship development (40\%), interaction of science, business and power (60\%), social and economic development (46\%), quality of life of the population (30\%). However, this scenario cannot be considered as the most effective, since it does not ensure a reduction in the level of corruption, administrative barriers and fraud, and the growth of state orders. 
The International Journal

ENTREPRENEURSHIP AND SUSTAINABILITY ISSUES

ISSN 2345-0282 (online) http://jssidoi.org/jesi/

2018 Volume 5 Number 4 (June)

http://doi.org/10.9770/jesi.2018.5.4(7)

\section{Scenario 4}
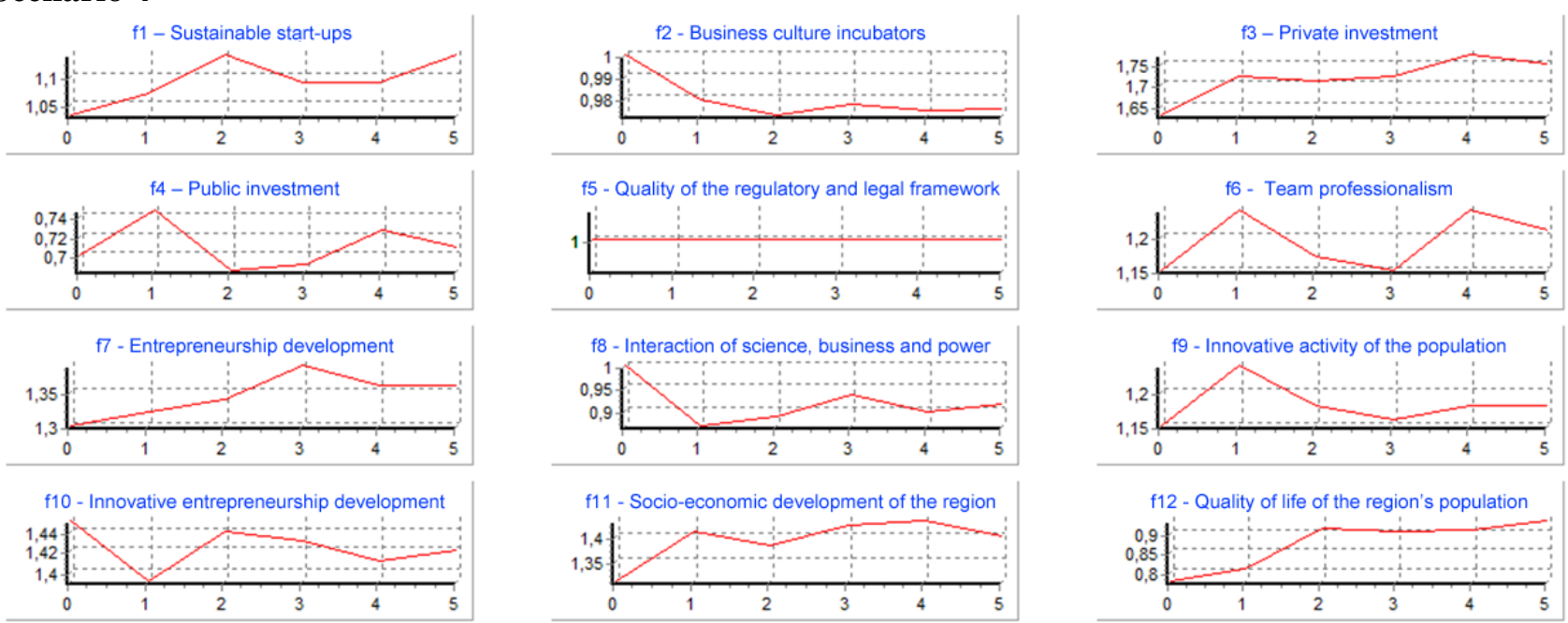

f5 - Quality of the regulatory and legal framework
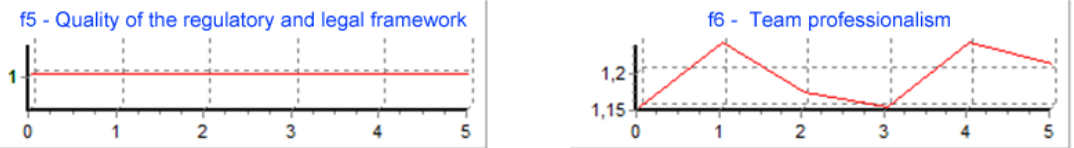

f8 - Interaction of science, business and power
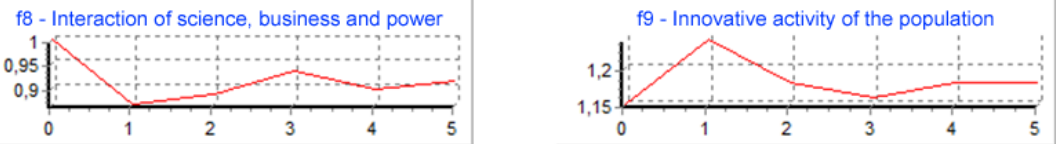

f11 - Socio-economic development of the region

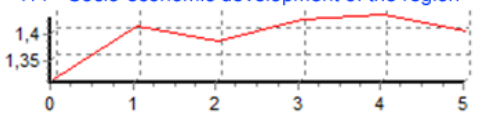

f12 - Quality of life of the region's population

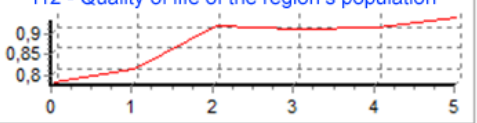

f13 - Demand for innovation
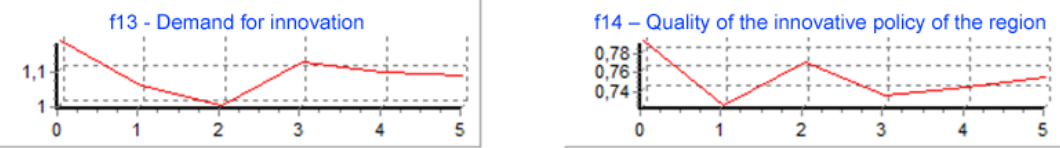

f16 - Administrative barriers

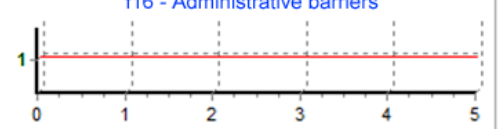

f17 - Corruption
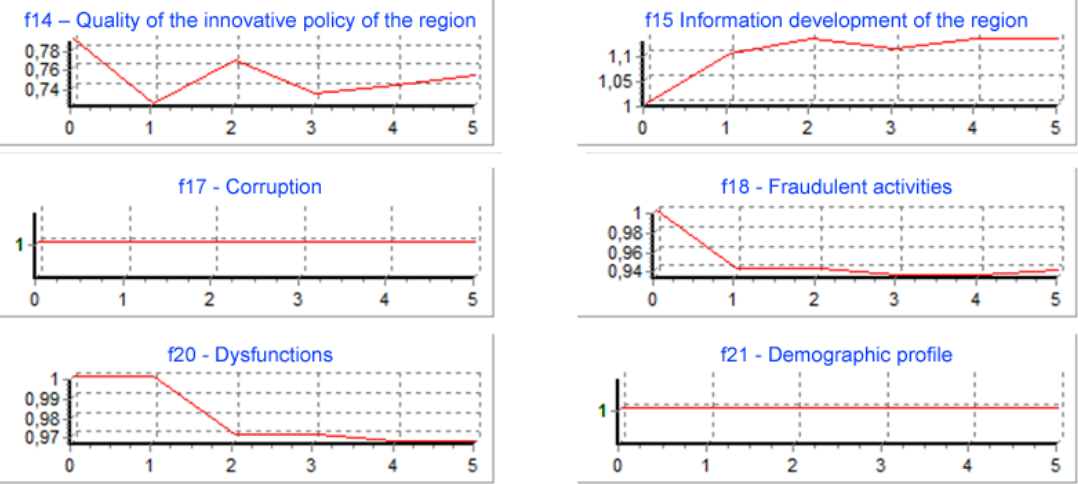

f21 - Demographic profile

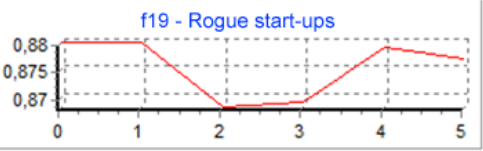

f23 - State order
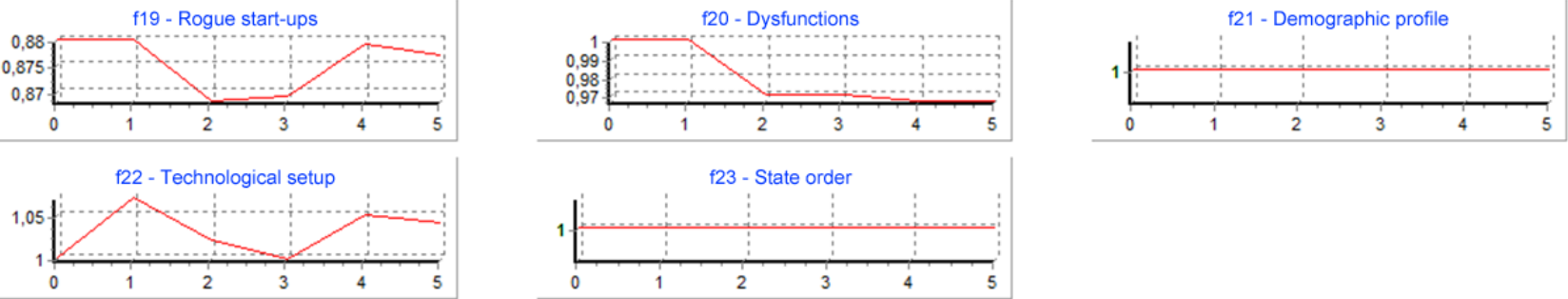

\section{Comment}

This scenario leads to the growth of the main socio-economic indicators of the region: sustainable start-ups (35\%), entrepreneurship development (20\%), the innovative entrepreneurship development (29\%), interaction of science, business and power (50\%), social and economic development (25\%), public investment (42\%), as well as to the reduction in the number of the rogue start-ups, dysfunction, and fraudulent activities. It contains resources for the further development of entrepreneurship, which are a consequence of the private business development (i.e., growth in private investment and tax revenue). Nevertheless, in modern conditions it is difficult to expect the outstripping growth of private investment in the economy of the region. In addition, this scenario does not ensure the reduction in the level of corruption, administrative barriers, and the growth of state orders (Orlova, 2017). 
The International Journal

ENTREPRENEURSHIP AND SUSTAINABILITY ISSUES

ISSN 2345-0282 (online) http://jssidoi.org/jesi/

2018 Volume 5 Number 4 (June)

http://doi.org/10.9770/jesi.2018.5.4(7)

\section{Scenario 5}
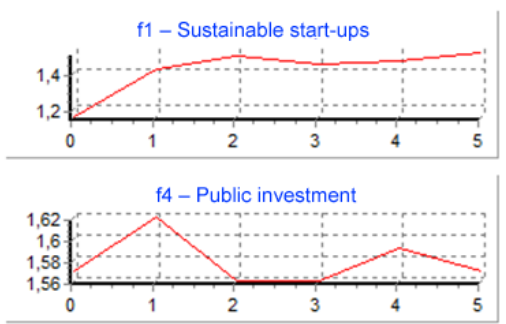

f7 - Entrepreneurship development
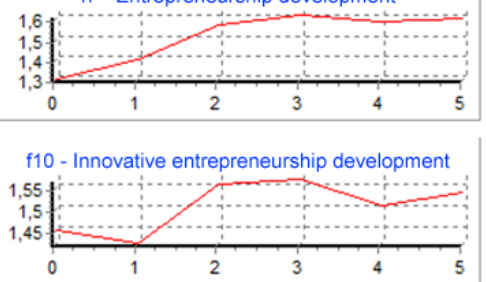

f13 - Demand for innovation

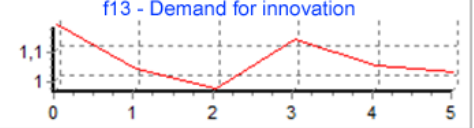

f16 - Administrative barriers
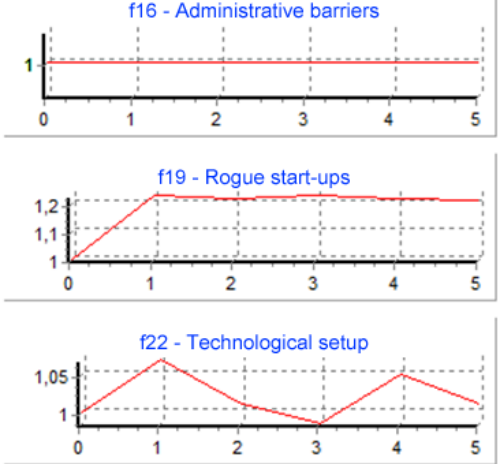

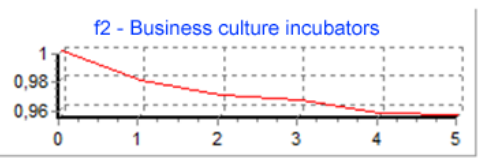

f5 - Quality of the regulatory and legal framework

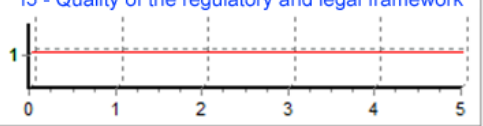

f8 - Interaction of science, business and power

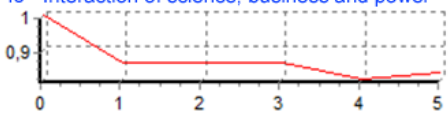

f11 - Socio-economic development of the region

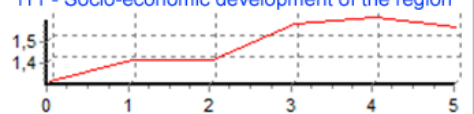

f14 - Quality of the innovative policy of the region

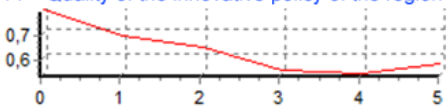

f17 - Corruption
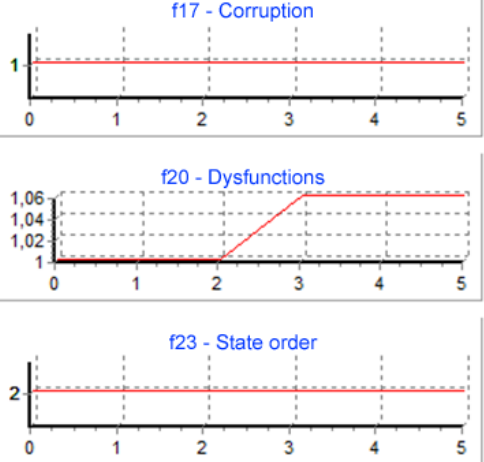

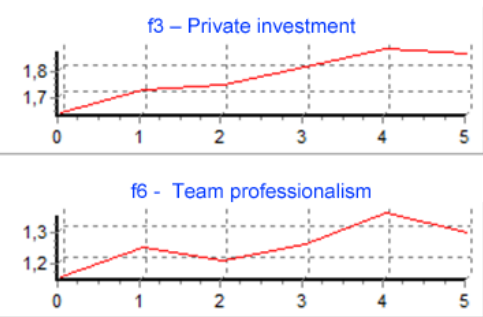

f9 - Innovative activity of the population

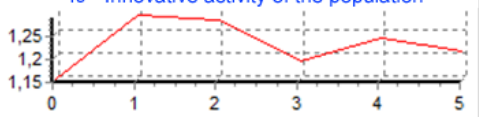

f12 - Quality of life of the region's population

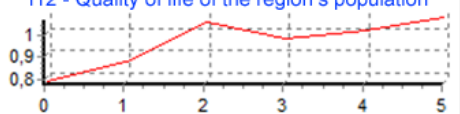

f15 Information development of the region

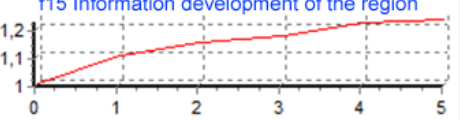

f18 - Fraudulent activities

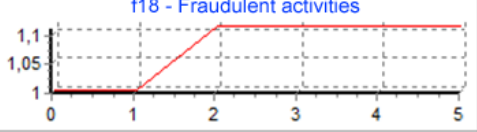

f21 - Demographic profile

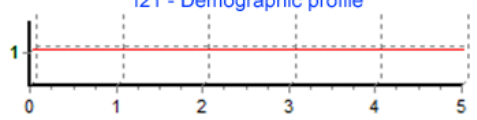

\section{Comment}

This scenario leads to the growth of the main socio-economic indicators of the region: sustainable start-ups (60\%), entrepreneurship development (23\%), the innovative entrepreneurship development (43\%), interaction of science, business and power (60\%), public investment (52\%), social and economic development (50\%), quality of life of the population (24\%), as well as a slight (from $1 \%$ to $4 \%$ ) decrease in the number of the rogue start-ups, corruption, fraudulent activities and administrative barriers. It contains resources for the further development of entrepreneurship, through the development of private business (i.e., growth in private investment and tax revenue). Nevertheless, a change in the regulatory and legal framework can adversely affect both the development of private business and the growth of state orders that stimulate the development of the economy of the region. 
The International Journal

ENTREPRENEURSHIP AND SUSTAINABILITY ISSUES

ISSN 2345-0282 (online) http://jssidoi.org/jesi/

2018 Volume 5 Number 4 (June)

http://doi.org/10.9770/jesi.2018.5.4(7)

\section{Scenario 6}

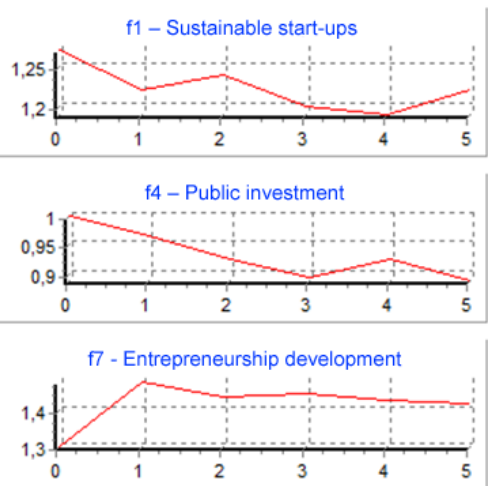

f10 - Innovative entrepreneurship development

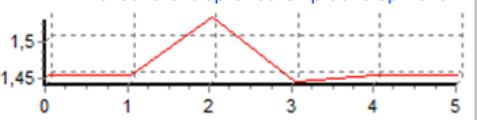

f13 - Demand for innovation

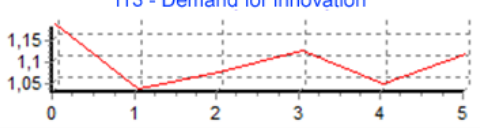

f16 - Administrative barriers

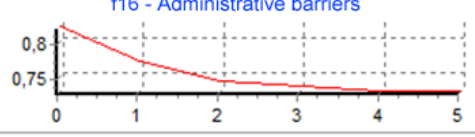

f19 - Rogue start-ups

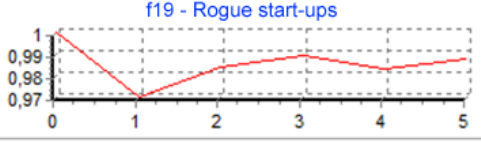

f22 - Technological setup

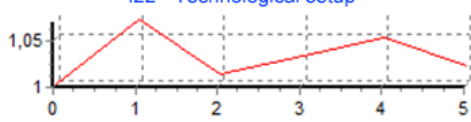

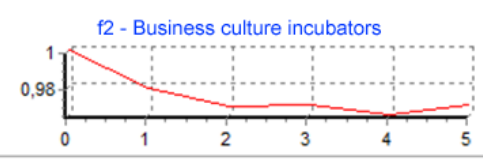

f5 - Quality of the regulatory and legal framework

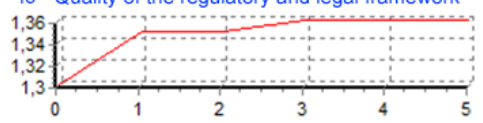

f8 - Interaction of science, business and power

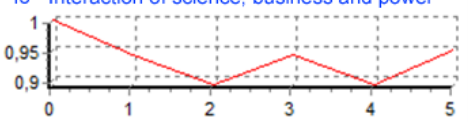

f11 - Socio-economic development of the region

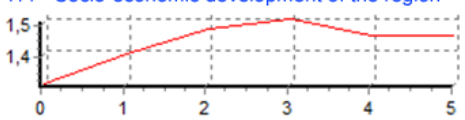

f14 - Quality of the innovative policy of the region

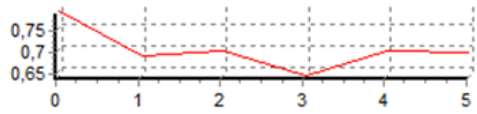

f17 - Corruption

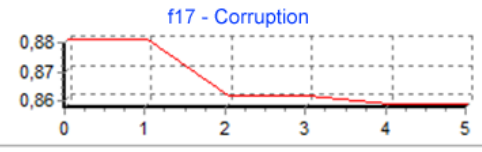

f20 - Dysfunctions

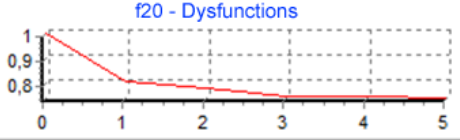

f23 - State order

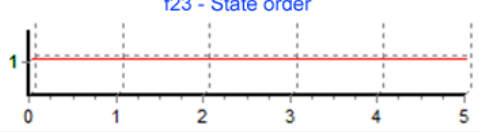

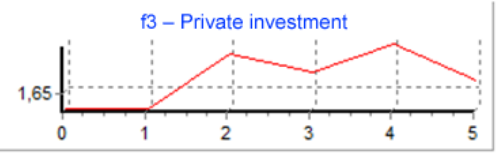

f6 - Team professionalism

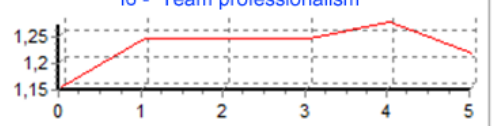

f9 - Innovative activity of the population

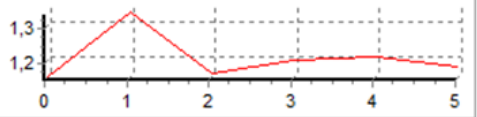

f12 - Quality of life of the region's population

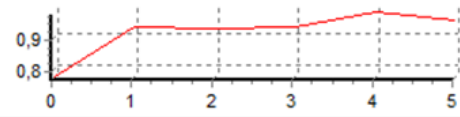

f15 Information development of the region
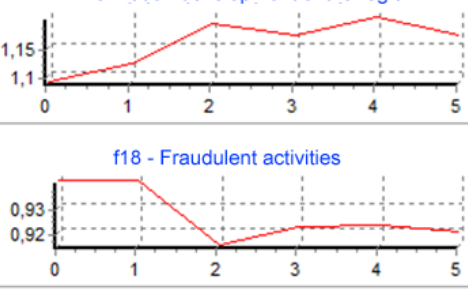

f21 - Demographic profile

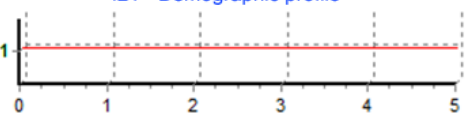

\section{Comment}

This scenario can be considered as one of the most effective, since the basic socio-economic indicators tend to grow, and the main negative factors tend to decline (corruption, etc.). The drawback of this scenario is related to the fact that it leads to the reduction in private investment: drastic changes of the regional legislation can contribute to this circumstance because private business may need time to adapt to the new regulatory framework.

For the Samara Region, scenario 4 is the most effective scenario for the growth of the basic socio-economic indicators of the region in the conditions of the invariable quality of the regulatory and legal framework. The number of the sustainable start-ups will grow by $35 \%$ and the number of the rogue start-ups will decrease by $3 \%$ over 6 years.

The quality of innovation policy will increase (by 29\%), as well as the level of informatization of the region (by 23\%). Entrepreneurship development will accelerate by $20 \%$ (i.e., the number of small and medium-sized enterprises will increase); innovative entrepreneurship development will grow by $29 \%$; interaction of science, business and power will improve by50\%; there will also be increase in technological setup (by 40\%) and in social and economic development (by 25\%). The quality of the technological setup, growing with an unchanged demographic profile, suggests that the economic growth is realized in this scenario through the 
The International Journal

ENTREPRENEURSHIP AND SUSTAINABILITY ISSUES

ISSN 2345-0282 (online) http://jssidoi.org/jesi/

2018 Volume 5 Number 4 (June)

http://doi.org/10.9770/jesi.2018.5.4(7)

introduction of advanced technologies, rather than through an extensive increase in the number of the employed.

The team professionalism will grow by $60 \%$, as well as the innovative activity of the population (by $60 \%$ ) and the quality of life (by 60\%). The demand for innovation will increase significantly (by 250\%).

This scenario contains resources for the further development of entrepreneurship, which are a consequence of the private business development (i.e., growth of private investment and tax revenues) and the growth of investments: private investment will increase at an average rate (by 27\%), and public investment will grow by $42 \%$.

Nevertheless, there is a weak development of business culture incubators (an increase by 5\%), a low level of fraud reduction (8\%) and a level of dysfunction (by 4\%). This scenario does not provide the reduction in the level of corruption, administrative barriers, and the growth of state orders.

\section{Discussion}

The most important tasks of the state policy in supporting innovative entrepreneurship are to create a positive environment for the formation of an integrated innovation sphere of the country, organically covering the entire set of innovative structures; to form an effective innovation infrastructure that provides favorable prerequisites for the establishment and operation of innovative start-ups in a competitive market (Orlova \& Afonin, 2015). The development of innovative entrepreneurship in the region is directly related to the formation of the regional system of support for innovative entrepreneurship, including through the development of business start-ups (Abernathy \& Uttenback, 1978).

The cognitive model developed within the framework of this study is based on a number of conclusions reflecting the features of modern start-ups and their interactions with the external environment.

1. Operation, effectiveness of start-ups leads to a decrease in the number of sustainable start-ups, to the emergence and growth of the number of the rogue start-ups that imitate business activity under the influence of such factors as corruption, administrative barriers and fraudulent activities.

2. Public investment, being associated with non-transparent administrative permits or bans, can contribute to increasing the share of the rogue start-ups. Private investment, being less connected with non-transparent administrative permits or bans, promotes increasing the number of effective, sustainable start-ups and can contribute to reducing the number of the rogue start-ups.

3. The quality of the regional legislation is a factor of the regional environment, which can affect directly the reduction of corruption, administrative barriers and fraud in the sphere of start-ups' activity. The active competitive environment of small and medium-sized business, innovative entrepreneurship, an increase in demand for innovations in the region are indirect factors that also ensure the reduction of the above mentioned negative phenomena.

4. The external environment has a significant reverse effect on the innovative start-ups. Thus, informatization promotes the growth of innovative activity of subjects of innovative development in the region. Globalization increases the transparency of the region, the level of external competition, which contributes to the growth of innovative activity. At the same time, there is a growing threat of information security, crime, terrorism, "brain drain", which negatively affects the innovative activity of subjects of innovative development. 
The International Journal

ENTREPRENEURSHIP AND SUSTAINABILITY ISSUES

ISSN 2345-0282 (online) http://jssidoi.org/jesi/

2018 Volume 5 Number 4 (June)

http://doi.org/10.9770/jesi.2018.5.4(7)

\section{Conclusions}

Summarizing the above, the following conclusions can be drawn as to the impact of innovative start-ups on socio-economic regional development:

- based on analytical and statistical data, expert assessments 23 key factors have been identified that show the influence of start-ups on regional development and the reverse impact, and groups of factors with a weak, moderate, strong influence were distinguished;

- the factors of the experimental cognitive model and the statistical indicators characterizing the regional social and economic development have been compared. This comparison is accompanied by the results of correlation analysis for quantitatively measurable factors;

- predictive scenario modeling of the effect of start-ups on regional development has been made. For the Samara Region, scenario 4 is the most effective scenario of "asymmetric" investments (private investment is growing at an average pace, and public investment is declining slightly), followed by scenario 6 (growth of private investment while improving the regulatory and legal framework).

Functioning of the regional innovative system enables to create actual economic conditions for effective organization of innovative entrepreneurship, increasing innovative activity and creating a favorable innovation environment, which in turn contributes to sustainable development of the region as a whole.

\section{References}

Abernathy, W. J.; Uttenback, J. W. 1978. Patterns of industrial innovation, Technology Review 80(7): 40-47.

Afonin, Yu. A.; Orlova, L. V. 2017. Social security - The welfare state - Social management, Sciences of Europe 2(13): 50-59. Available on the Internet: http://european-science.org/wp-content/uploads/2017/04/VOL-2-No-13-13-2017.pdf

Akhmetshin, E. M. 2017. The system of internal control as a factor in the integration of the strategic and innovation dimensions of a company's development, Journal of Advanced Research in Law and Economics 8(6): 1684-1692. https://doi.org/10.14505/jarle.v8.6(28).03

Akhmetshin, E. M.; Artemova, E. I.; Vermennikova, L. V.; Shichiyakh, R. A.; Prodanova, N. A.; Kuchukova, N. M. 2017. Management of investment attractiveness of enterprises: Principles, methods, organization, International Journal of Applied Business and Economic Research 15(23): 71-82.

Archibugi, D.; Howells, J.; Michie, J. 1999. Innovation policy in a global economy. Cambridge: Published by Cambridge University Press. Available on the Internet: http://bookre.org/reader?file=1110473

Autio, E. 1998. Evaluation of RTD in regional system of innovation, European Planning Studies 6(2): 131-140. https://doi.org/10.1080/09654319808720451

Dagaev, A. A. 2000. Levers of innovative growth, Problems of Theory and Practice of Management 5: 31-38.

Dakhin, A. V.; Danilova, O. S.; Denisov, V. N.; Guseva, M. A. 2011. Synergetic basis of the cognitive model of regional dynamics of changes in the state of small and medium businesses, Power 1: 42-49.

Dobrenkov, V. I.; Afonin, Yu. A.; Gagarinskaya, G. P.; Orlova, L. V.; Pronina, N. N.; Sabirova, G. T. 2017. Innovative development: International experience of intellectual property commercialization, European Research Studies Journal XX(4A): 241-252. Available on the Internet: https://www.ersj.eu/index.php?option=com_docman\&task=cat_view\&gid=111\&dir=ASC\&order=name\&Itemid=154\&limit=5\&limits $\underline{\operatorname{tart}=15}$

Dosi, G.; Freeman, C.; Nelson, R.; Silverberg, G.; Soete, L. 1988. Technical Change and Economic Theory. London: Published by Pinter.

Drucker, P. F. 2007. Innovation and Entrepreneurship. Moscow: Published by Wiliams.

Fatkhutdinov, R. 2004. Innovative management. St. Petersburg: Published by Peter. 
The International Journal

ENTREPRENEURSHIP AND SUSTAINABILITY ISSUES

ISSN 2345-0282 (online) http://jssidoi.org/jesi/

2018 Volume 5 Number 4 (June)

http://doi.org/10.9770/jesi.2018.5.4(7)

Glazyev, S. Yu. 1993. The theory of long-term technical and economic development. Moscow: Published by Vla-Dar.

Gokhberg, L. M. 2003. Russian National Innovation System under Conditions of the "New Economy", Issues of Economics 3: $26-44$.

Hayek, F. 2005. The Road to Serfdom. Moscow: Published by Novoe izdatelstvo. Available on the Internet: http://library.fa.ru/files/Hayek-Road_to_Serfdom.pdf

Howells, J. 2004. Innovation, Consumption and Services: Encapsulation and the Combinatorial Role of Services, The Services Industries Journal 24: 19-36. https://doi.org/10.1080/02642060412331301112

Kazantsev, A. K.; Firsova, S. A.; Serova, L. S.; Belko, S. A. 2003. Features of the development of national and regional innovative systems in the Russian Federation. St. Petersburg: Published by Center for Research and Statistics of Science of the Ministry of Industry and Science of the Russian Federation, The Russian Academy of Sciences.

Kosharnaya, G. B. 2016. The influence of values of the domestic business on integration processes in society, Power 9: 133-137. Available on the Internet: http://jour.isras.ru/upload/journals/2/articles/4643/submission/original/4643-8602-1-SM.pdf

Kovalev, G. D. 2000. Innovative communications. Moscow: Published by UNITY-DANA.

Kozubíková, L.; Homolka, L.; Kristalas, D. 2017. The Effect of Business Environment and Entrepreneurs' Gender on Perception of Financial Risk in The Smes Sector, Journal of Competitiveness 9(1): 36-50. https://doi.org/10.7441/joc.2017.01.03

Livshits, V. N.; Livshits, S. V. 2000. On one approach to assessing the efficiency of industrial investment in Russia, in Evaluation of investment efficiency. Issue 1. Moscow: Central Economics and Mathematics Institute Press, Russian Academy of Sciences, 56-68.

Lundvall, B.-A. 1992. National innovation system: towards a theory of innovation and interactive learning. London: Published by Pinter Publishers.

Lvov, D. S. 2003. Perspectives of the long-term social and economic development of Russia, Bulletin of the Russian Academy of Sciences 73(8): 43-51.

Maslennikova, N. P. 2001. Management of an innovative organization. Moscow: Published by State University of Management Press.

Medynsky, V. G.; Skamay, L. G. 2005. Innovative entrepreneurship. Moscow: Published by UNITY-DANA.

Nelson, R. R. 1993. National innovation systems: a comparative analysis. Oxford: Published by Oxford University Press. Available on the Internet: http://bookre.org/reader?file=835238

Obraztsova, O.; Chepurenko, A. Yu. 2008. The Development of Russian Private Entrepreneurship in Cross-country Comparison, Issues of Economics 8: 91-107.

Orlova, L. V. 2017. Innovative projects promotion model. Problems of methodology and methods of monitoring social and economic regional development of the Russian Federation: proceedings of the All-Russian Scientific-Practical Conference: Ed. by Sedov, A. I.; Konakov, V. V.; Vdovin, S. M.; Gagaev, A. A.; Kozin, V. V.; Lisunova, L. M.; Minichkina, V. P.; Pakshina, A. I.; Pisachkin, V. A.; Ruskina, E. S.; Fadeeva, I. M.; Tsvetkova, I. V. September 5, Saransk, Russia. Saransk: The Scientific Center of Social and Economic Monitoring, 169-175.

Orlova, L. V.; Afonin, Y. A. 2015. Modern management tools: benchmarking and leasing, Oxford Journal of Scientific Research 3(1/9): 292-300.

Rakhimova, G. M. 2014. Structural elements of the sources of potential of regional economy, Contemporary economic issues 1: https://doi.org/10.24194/11406

Rakhimova, G. M. 2014. Structural elements of the sources of potential of regional economy, Contemporary economic issues 1: https://doi.org/10.24194/11406

Razminienė, K.; Tvaronavičienė, M. 2017. Economic globalization and its impacts on clustering, Terra Economicusn 15 (2): 109-121 https://doi.org/10.23683/2073-6606-2017-15-2-109-121

Say, J.-B. 2001. A Treatise on Political Economy. Kitchener: Published by Batoche Books. Available on the Internet: https://socialsciences.mcmaster.ca/econ/ugcm/3113/say/treatise.pdf 
The International Journal

ENTREPRENEURSHIP AND SUSTAINABILITY ISSUES

ISSN 2345-0282 (online) http://jssidoi.org/jesi/

2018 Volume 5 Number 4 (June)

http://doi.org/10.9770/jesi.2018.5.4(7)

Schumpeter, J. 2007. The Theory of Economic Development. Capitalism, Socialism and Democracy. Moscow: Published by Eksmo.

Tatarkin, A. I. 2013. Innovation direction of the average region development in the modernization of the Russian Federation, Contemporary economic issues 3: https://doi.org/10.24194/31311

Todtling, F.; Kaufmann, A. 1999. Innovation systems in regions of Europe: a comparative perspective, European Planning Studies 7(6): 699-717. https://doi.org/10.1080/09654319908720549

Tvaronavičienè, M.. 2017. Clusters, innovations and energy efficiency: if relationship could be traced, Marketing and Management of Innovations 2: 382 - 391 https://doi.org/10.21272/mmi.2017.2-35

Vasiliev, V. N. 2000. Entrepreneurship and success factors, Russian Journal of Entrepreneurship 1: 39-45.

Vinogradova, N. A. 2015. Methods of evaluation of social development, Contemporary economic issues 1 https://doi.org/10.24194/11506

Vojtovič, S. 2016. The Impact of The Structural Funds on Competitiveness of Small and Medium-Sized Enterprises, Journal of Competitiveness 8(4): 30-45. https://doi.org/10.7441/joc.2016.04.02

Wroblowská, Z. 2016. Requirements for Brand Managers and Product Managers Responsible for Competitiveness of Product and Brands, Journal of Competitiveness 8(3): 5-21. https://doi.org/10.7441/joc.2016.03.01

Zavlin, P. N.; Baryutin, L. S.; Kazantsev, A. K.; Mindeli, L. E. (Eds.). 2004. Fundamentals of innovative management (theory and practice). Moscow: Published by Ekonomika.

Ludmila ORLOVA is a Doctor of Sociology, Professor of the Sociology, Political Science and History of the Fatherland Department of the Samara State Technical University. Research interests: socio-economic problems of regional development, entrepreneurship development in the Customs Union countries, personnel management, technologies of conflict management in the organization, mediation in educational activity, digital economy

ORCID ID: orcid.org/0000-0003-2790-3149

Galina GAGARINSKAYA is a Doctor of Economic Sciences, Professor, Head of the Department of Economics and Management Organization of Samara State Technical University. Research interests: socio-economic problems of regional labor market development, problems of motivation and stimulation of labour in industry, research of tendencies and regularities of human activity; social and labour relations; labour resources and workforce reproduction; organizational and socio-economic mechanisms of labour management.

ORCID ID: orcid.org/0000-0001-5174-0824

Yuliya GORBUNOVA is a Candidate of Economics, Associate Professor of the department "Economics and Organization Management" of the Samara State Technical University. Research interests: socio-economic problems of regional labor market development, problems of labor organization and rationing; incomes and salaries at enterprises of all organizational-legal forms and scales of activity; progressive international norms and standards in the field of labor economics, social and labor relations at small and medium business enterprises, organizational and socio-economic mechanisms of management in the subjects of small and medium entrepreneurship.

ORCID ID: orcid.org/0000-0003-0699-6075

Olga KALMYKOVA is a Candidate of Pedagogics, Associate Professor of the department "Economics and Organization Management" of the Samara State Technical University. Research interests: socio-economic problems of regional development, personnel policy formation in the oil and gas economy sector, problems of strategic personnel management at an industrial enterprise, social technologies of conflicts and stresses management in the service industry organization, formation of conflictological and managerial competence of the organization head.

ORCID ID: orcid.org/0000-0003-0933-0332

Copyright (C) 2018 by author(s) and VsI Entrepreneurship and Sustainability Center

This work is licensed under the Creative Commons Attribution International License (CC BY).

http://creativecommons.org/licenses/by/4.0/ 